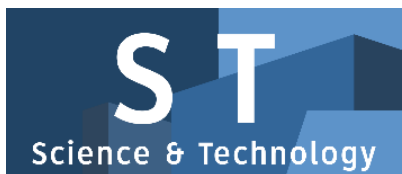

PAPER - OPEN ACCESS

\title{
Rancang Bangun Alat Penukar Kalor Shell And Tube Dengan Satu Laluan Cangkang Dan Dua Laluan Tabung Sebagai Pemanas Air
}

$\begin{array}{ll}\text { Author } & : \text { Farel H. Napitupulu } \\ \text { DOI } & : 10.32734 / \text { st.v1i2.289 } \\ \text { Electronic ISSN } & : 2654-7082 \\ \text { Print ISSN } & : 2654-7074\end{array}$

Volume 1 Issue 2 - 2018 TALENTA Conference Series: Science \& Technology (ST)

\section{(ㅇ) $(1)$}

This work is licensed under a Creative Commons Attribution-NoDerivatives 4.0 International License.

Published under licence by TALENTA Publisher, Universitas Sumatera Utara
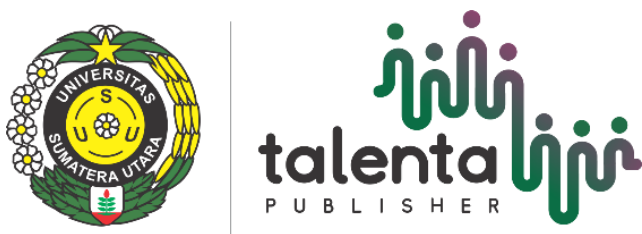


\title{
Rancang Bangun Alat Penukar Kalor Shell And Tube Dengan Satu Laluan Cangkang Dan Dua Laluan Tabung Sebagai Pemanas Air
}

\author{
Farel H. Napitupulu ${ }^{a}$, Tekad Sitepu ${ }^{a}$, Jefry Kusumaa ${ }^{a}$ Agus Wijaya ${ }^{a}$ \\ ${ }^{a}$ Departemen Teknik Mesin Universitas Sumatera Utara, Kampus USU Medan
}

\begin{abstract}
Abstrak
Limbah air panas yang dibuang langsung tanpa diproses pasti akan mengakibatkan efek buruk terhadap ekosistem air. Dalam penelitian ini bertujuan untuk membuat suatu rancang bangun alat penukar kalor yang memanfaatkan energi panas dari limbah air panas pabrik pupuk yang bertujuan untuk memanaskan air dan akan digunakan sebagai air panas di pemandian perumahan karyawan pabrik pupuk. Dengan memanfaatkan energi panas dari limbah air panas tersebut maka temperatur limbah air panas ini juga akan turun dan selanjutnyadapat dibuang ke sungai tanpa membahayakan ekosistem di sungai.

Secara ringkas, didapat alat penukar kalor berukuran panjang $1,64 \mathrm{~m}$, lebar $0,48 \mathrm{~m}$, dan tinggi $2,1 \mathrm{~m}$, Panjang total pipa pada alat penukar kalornya adalah $2,7 \mathrm{~m}$ berdiameter $13 \mathrm{~mm}$, dan shellnya mempunyai panjang $1,35 \mathrm{~m}$ dan berdiameter $70 \mathrm{~mm}$, volume pada tangki Alat penukar ini sebesar 27 Liter. Pada tabung dalam APK shell \& tube, material yang digunakan adalah tembaga dengan nilai konduktivitas sebesar $385 \mathrm{~W} / \mathrm{mK}$ sedangkan pada APK tabung sepusat, material yang digunakan adalah aluminium dengan nilai konduktivitas sebesar $205 \mathrm{~W} / \mathrm{mK}$. Sedangkan efektifitas terbesar setelah dilakukan percobaan adalah 35,4040\%.
\end{abstract}

Kata Kunci: APK tipe shell and tube; satu cangkang dua laluan; pemanas air

\section{Pendahuluan}

Perlu diketahui bahwa limbah panas yang dibuang langsung tanpa diproses pasti akan mengakibatkan efek buruk terhadap lingkungan. Salah satu contoh dari kondisi inilah adalah limbah air panas dari pabrik pupuk yang langsung dibuang ke sungai. Berdasaran hasil survei lapangan yang dilakukan tim pengusul bahwa selama ini limbah air panas yang bertemperatur sekitar $55^{\circ} \mathrm{C}-60^{\circ} \mathrm{C}$ dari pembangkit pabrik pupuk ini langsung dibuang ke sungai sehingga meningkatkan temperatur air dan menimbulkan pencemaran termal. Kenaikan suhu $10^{\circ} \mathrm{C}$ derajat dari biasanya dapat mempercepat aktivitas metabolisme biota air, sedangkan masing-masing biota air memiliki kcepatan metabolik yang berbeda, maka biota air hanya dapat hidup pada suhu tertentu yang berbeda-beda untuk tiap kelompok biota. Populasi biota air akan menurun pada suhu tinggi,hanya sedikit jenis hewan yang dapat hidup pada temperatur diatas $45^{\circ}$ C.Dampak buruk dari pembuangan limbah air panas ini adalah perubahan temperatur secara tidak alamiah berdampak langsung terhadap biota dimana daya dukung habitatnya menjadi hilang. Sebagai contoh pada habitat terumbu karang dimana dengan berubahnya temperatur maka tingkat kelarutan oksigen dan kalsium karbonat di air akan ikut berubah.

Berdasarkan hal terserbut di atas maka diusulkanlah suatu rancang bangun alat penukar kalor yang digunakan untuk memanfaatkan energi panas dari limbah air panas pabrik pupuk yang bertujuan untuk memanaskan air. Dengan 
menmanfaatkan energi panas dari limbah air panas tersebut maka temperatur limbah air panas ini juga akan turun dan selanjutnyadapat dibuang ke sungai tanpa membahayakan ekosistem di sungai.

\section{Studi Literatur}

\subsection{Teori Dasar Alat Penukar Kalor}

Alat penukar kalor (APK) adalah alat yang memungkinkan terjadinya perpindahan panas diantara dua fluida yang memiliki temperatur yang berbeda tanpa mencampurkan kedua fluida tersebut (Hewitt, 1994). Alat penukar kalor biasanya digunakan secara praktis di dalam aplikasi yang luas, seperti dalam kasus pemanasan dan sistem pengkondisian udara, proses-proses kimia dan proses pembangkitan tenaga (Davood et. al., 2017). Alat penukar kalor berbeda dengan ruangan pencampuran yakni alat penukar kalor tidak memperbolehkan kedua fluida bercampur. Sebagai contoh, pada radiator mobil, panas dipindahkan dari air panas yang mengalir melalui pipa yang terdapat pada radiator yang ditambahkan plat pada jarak yang kecil dengan melewatkan udara diantaranya. Perpindahan panas pada alat penukar kalor biasanya terdiri dari konveksi pada fluida dan konduksi pada dinding yang memisahkan kedua fluida. Pada saat menganalisa alat penukar kalor, sangat diperlukan untuk menggunakan koefisien perpindahan panas menyeluruh $U$ yang memungkinkan untuk menghitung seluruh efek dari perpindahan panas. Laju perpindahan panas diantara kedua fluida terletak pada alat penukar kalor yang bergantung pada perbedaan temperatur pada suatu titik, yang bervariasi sepanjang alat penukar kalor. Pada saat menganalisis alat penukar kalor, umumnya bekerja dengan menggunakan logarithmic mean temperature difference LMTD, yang sebanding dengan perbedaan temperatur ratarata diantara kedua fluida sepanjang alat penukar kalor. Ketika dua temperatur tidak diketahui sehingga tidak dapat dianalisis maka dapat digunakan metode keefektifan NTU [1][5].

\subsection{Standarisasi Tabung Alat Penukar Kalor}

Perlu diketahui bahwa untuk alat-alat ini terdapat suatu terminologi yang telah distandarkan untuk menamai alat dan bagian-bagian alat tersebut yang dikeluarkan oleh Asosiasi pembuat Heat Exchanger yang dikenal dengan Tubular Exchanger Manufacture's Association (TEMA). Standarisasi tersebut bertujuan untuk melindungi para pemakai dari bahaya kerusakan atau kegagalan alat, karena alat ini beroperasi pada temperature dan tekanan yang tinggi. Di dalam standar mekanik TEMA (TEMA, 2007), terdapat dua macam kelas alat penukar kalor yaitu kelas R, yaitu untuk peralatan yang bekerja dengan kondisi berat, misalnya untuk industri minyak dan kimia berat dan kelas C, yaitu yang dibuat untuk general purpose, dengan didasarkan pada segi ekonomis dan ukuran kecil, digunakan untuk proses-proses umum industri.

\subsection{Alat Penukar Kalor Shell And Tube}

Alat penukar kalor shell and tube heat umumnya digunakan dalam kondisi tekanan relatif tinggi yang terdiri dari sebuah selongsong yang di dalamnya disusun suatu annulus dengan rangkaian tertentu untuk mendapatkan luas permukaan yang optimal (Emerson et.al., 2017). Fluida mengalir di selongsong maupun di annulus sehingga terjadi perpindahan panas antara fluida dengan dinding annulus misalnya triangular pitch (pola segitiga) dan square pitch (pola segiempat). 


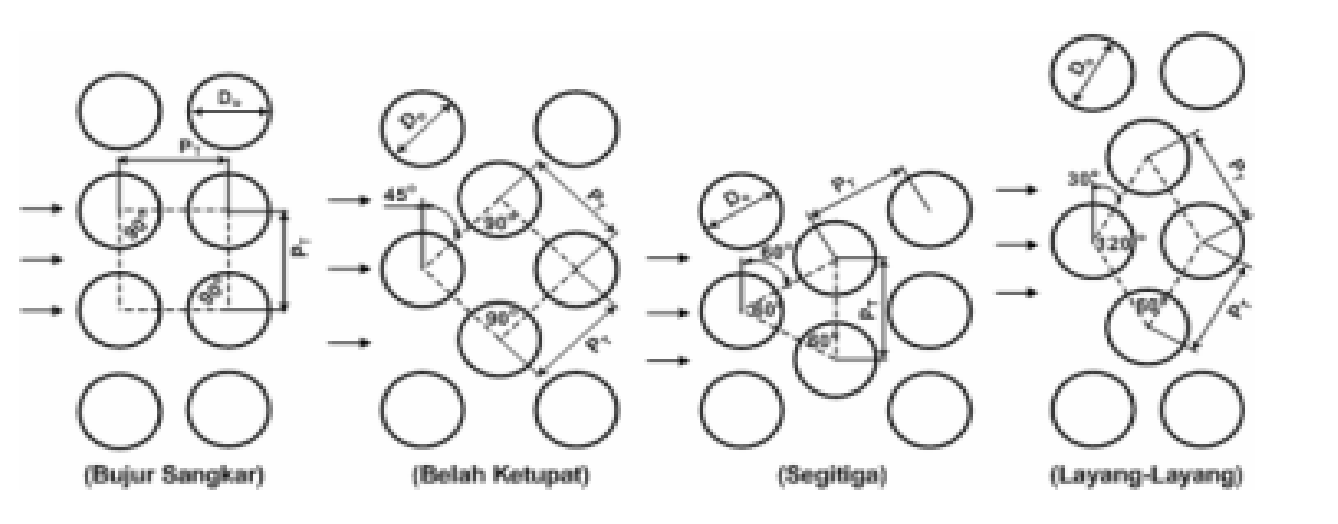

Gambar 2.1 Bentuk susunan tabung (Incropera, 2008)

Keuntungan square pitch adalah bagian dalam tube-nya mudah dibersihkan dan pressure drop-nya rendah ketika mengalir fluida di dalamnya (Gabriel, 2017). Keuntungan dari alat penukar kalor tipe shell and tube adalah (Bhanuchandrarao, 2015) antara lain konfigurasi yang dibuat akan memberikan luas permukaan yang besar dengan bentuk atau volume yang kecil, mempunyai lay-out mekanik yang baik, bentuknya cukup baik untuk operasi bertekanan, menggunakan teknik fabrikasi yang sudah mapan (well-astablished), dapat dibuat dengan berbagai jenis material, dimana dapat dipilih jenis material yang digunakan sesuai dengan temperatur dan tekanan operasi, mudah membersihkannya dan konstruksinya sederhana, pemakaian ruangan relatif kecil.

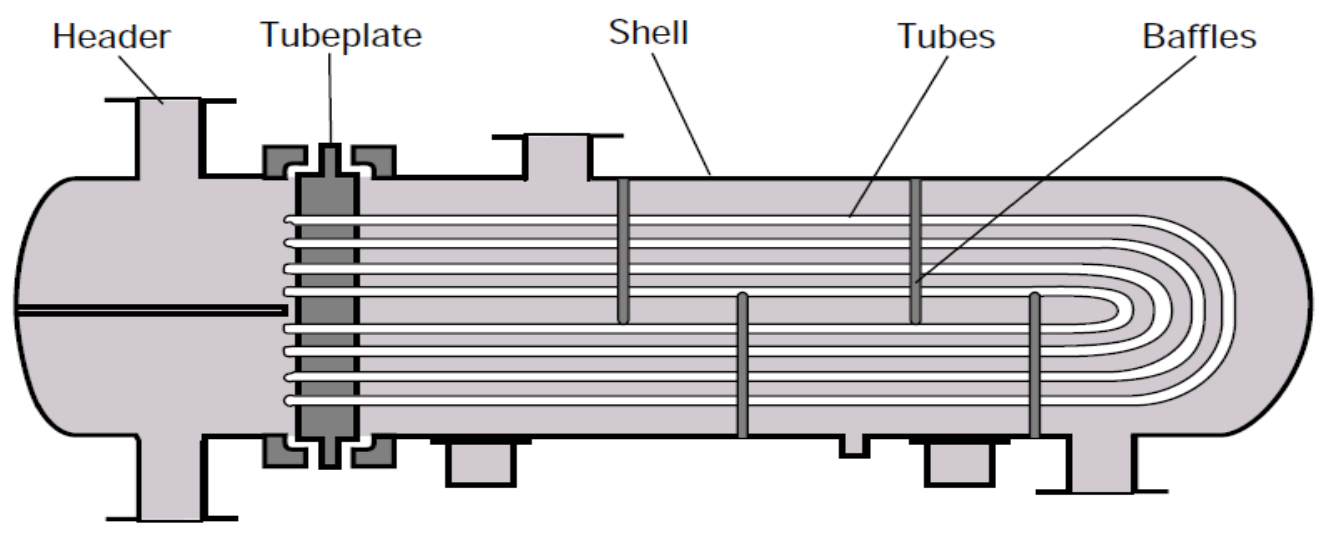

Gambar 2.2 Alat penukar kalor tipe shell and tube

Kerugian penggunaan shell and tube heat exchanger adalah semakin besar jumlah lewatan maka semakin banyak panas yang diserap tetapi semakin sulit perawatannya (Hamed et. al., 2017).

\subsection{Aliran Di Dalam Pipa}

Cairan atau gas yang melewati pipa atau duct biasanya digunakan dalam proses pemanasan ataupun pendinginan. Untuk aliran di dalam pipa yang memiliki penampang lingkaran maka bilangan Reynold didefenisikan sebagai 


$$
\operatorname{Re}=\frac{\rho V D}{\mu}=\frac{V D}{v}
$$

Dengan menghitung bilangan Reynold, dapat ditentukan jenis aliran yang terjadi (Kuppan, 2005) yaitu Re < 2300 aliran laminar, $2300 \leq \mathrm{Re} \leq 10000$ aliran transisi dan $\operatorname{Re}>10000$ aliran turbulen. Untuk aliran laminar dengan pipa berbentuk lingkaran dengan panjang $L$ dengan temperatur permukaan yang konstan, bilangan Nusselt rata-rata untuk daerah masuk termal dapat dicari dengan persamaan (Kern D. Q ,1950) :

$$
\mathrm{Nu}=3.66+\frac{0,065(D / L) \operatorname{Re} \operatorname{Pr}}{1+0,04[(D / L) \operatorname{Re} \operatorname{Pr}]^{2 / 3}}
$$

Untuk aliran transisi dapat dihitung dengan menggunakan persamaan (Lienhard, 2008)

$$
\mathrm{Nu}=\frac{(f / 8)(\operatorname{Re}-1000) \operatorname{Pr}}{1+12,7(f / 8)^{0.5}\left(\operatorname{Pr}^{2 / 3}-1\right)}
$$

Persamaan ini berlaku dengan ketentuan pada $0,5 \leq \operatorname{Pr} \leq 2000$ dan $3 \times 10^{3}<\operatorname{Re}<5 \times 10^{6}$.

Untuk menghitung faktor gesekan yang terjadi dapat dihitung dengan persamaan (Lienhard, 2008):

$$
f=(0,790 \ln \mathrm{Re}-1,64)^{-2}
$$

Untuk aliran turbulen berkembang penuh didalam pipa yang halus, sebuah persamaan sederhana untuk menghitung bilangan Nusselt dapat diperoleh yakni [3]:

$$
\begin{gathered}
\mathrm{Nu}=0,023 \operatorname{Re}^{0,8} \operatorname{Pr}^{1 / 3} \\
\text { dengan syarat bahwa }: 0,7 \leq \operatorname{Pr} \leq 160, \quad \operatorname{Re}>10000
\end{gathered}
$$

\subsection{Faktor Pengotoran}

Performansi alat penukar kalor biasanya semakin menurun dengan bertambahnya waktu pemakaian sebagai akibat terjadinya penumpukan kotoran pada permukaan alat penukar kalor (Saleh et. al., 2017). Lapisan kotoran tersebut menimbulkan hambatan tambahan pada proses perpindahan panas dan mengakibatkan penurunan laju perpindahan panas pada alat penukar kalor. Penumpukan kotoran pada alat penukar kalor disebut faktor pengotoran $R_{f} y a n g$ menjadi ukuran dalam tahanan termal.

Menurut Hewitt(1994), mekanisme dimana permukaan menjadi berkerak dapat dipisahkan dan diklasifikasikan berdasarkan proses antara lain :

- Crystallization fouling ; Pengendapan dan/atau kristal pada permukaan.

- Particulate fouling; Akumulasi partikel dari aliran fluida pada permukaan.

- Chemical reaction fouling ; Pengendapan terbentuk akibat dari satu atau lebih reaksi kimia terhadap pereaksi yang terkandung dalam fluida yang mengalir.

- Corrossion fouling : Efek dari korosi pada permukaan alat penukar kalor itu sendiri ataupun bagian lain yang terdapat pada bagian proses. 


\subsection{Analisis Alat Penukar Kalor Dengan Metode Log Mean}

\subsubsection{Temperature Difference (Lmtd)}

Dalam merancang ataupun memprediksi performansi alat penukar kalor, sangatlah perlu untuk menghubungkan antara laju perpindahan panas total terhadap temperatur fluida yang masuk dan keluar, koefisien perpindahan panas menyeluruh, dan luas permukaan total untuk laju perpindahan panas (Weimin et. al., 2017). Persamaan perpindahan panas antara fluida panas dan fluida dingin adalah setimbang. Jika $Q$ adalah laju perpindahan panas antara fluida panas dengan fluida dingin dan dengan mengabaikan perpindahan panas yang terjadi pada alat penukar kalor dengan lingkungan, mengabaikan perubahan energi potensial dan energi kinetik, dan dengan mengaplikasikan persamaan energi steady, diperoleh persamaan yang ada di dalam perhitungan, seperti tampak pada gambar 2.3. [5].

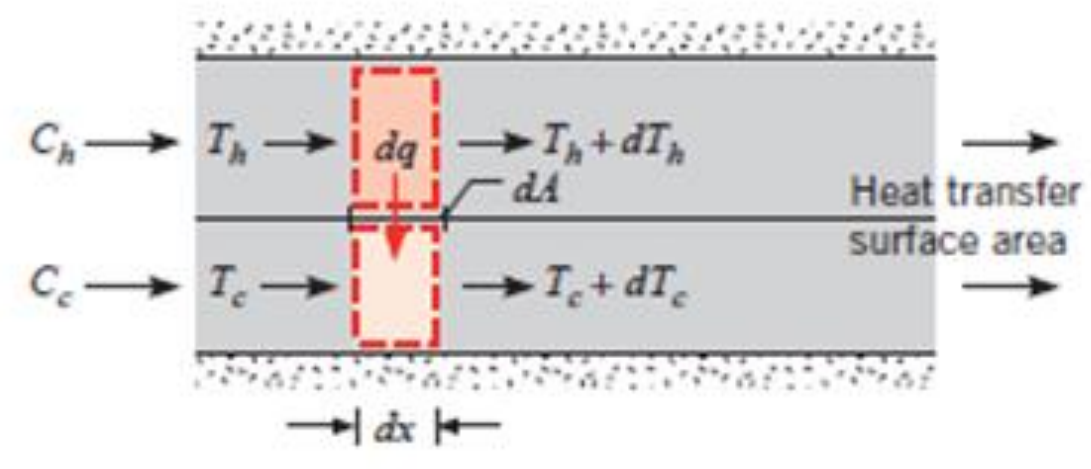

Gambar 2.3. Kesetimbangan energi total untuk pada sebuah alat penukar kalor

$$
q=\dot{m}_{c}\left(i_{c, o}-i_{c, i}\right)=\dot{m}_{h}\left(i_{h, i}-i_{h, o}\right)
$$

$i$ adalah entalpi fluida. Subscript $h$ dan $c$ adalah menandakan fluida hot (panas) dan fluida cold (dingin), sedangkan subscript $i$ dan $o$ adalah kondisi inlet (masuk) dan outlet (keluar) fluida. Jika fluida tidak mengalami perubahan fasa dan diasumsikan pada kondisi panas jenis yang konstan, maka persamaan menjadi

$$
Q=\dot{m}_{h} c_{p, h}\left(T_{h, i}-T_{h, o}\right)=\dot{m}_{c} c_{p, c}\left(T_{c, o}-T_{c, i}\right)
$$

Jika $T_{h}$ dan $T_{c}$ adalah suhu kedua fluida yang berada di elemen $d A$ dari permukaan alat penukar kalor maka besarnya laju perpindahan panas yang terjadi diantara kedua fluida melalui elemen $d A$ dapat dituliskan menjadi bentuk

$$
d q=U d A\left(T_{h}-T_{c}\right)
$$




\section{METODOLOGI PENELITIAN}

\subsection{Alat dan Bahan}

\subsubsection{Alat}

Alat yang dipakai dalam penelitian ini terdiri dari :

Alat penukar kalor tabung sepusat

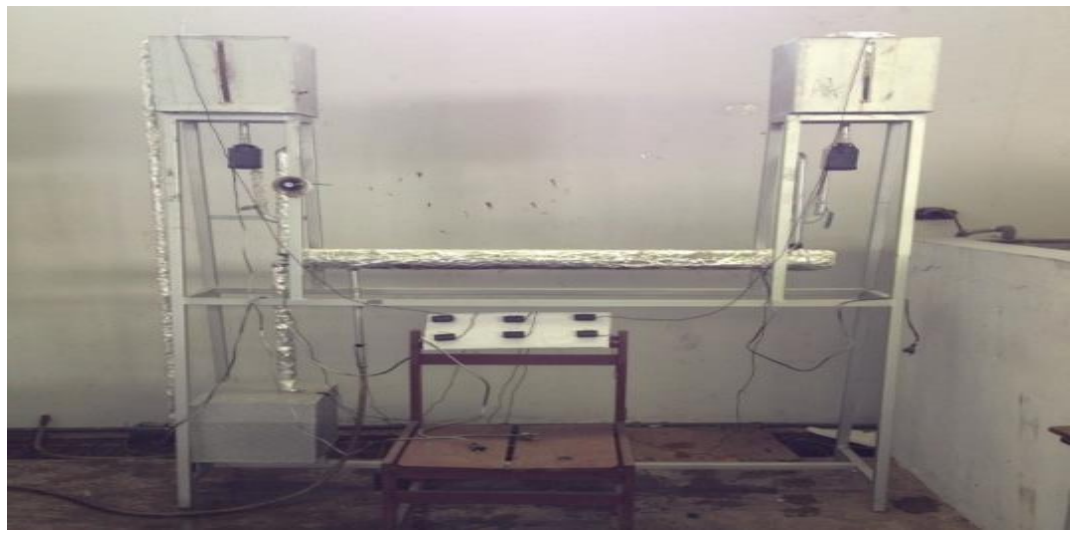

Gambar 3.1 alat penukar kalor

- Termometer digital Alat ukur ini berfungsi untuk mengukur suhu masukan dan suhu keluaran dari masing-masing fluida yaitu fluida panas dan fluida dingin. Suhu yang didapat akan dimunculkan pada display yang terdapat pada alat ukur tersebut. Berikut adalah gambar dari alat ukur suhu dari alat penukar kalor tersebut.

- Flowmeter berfungsi mengetahui berapa kapasitas aliran yang terjadi pada masing-masing pipa yaitu pada pipa yang mengalirkan fluida panas dan pipa yang mengalirkan fluida dingin.

- Water Heater digunakan untuk memanaskan fluida yang ada didalam kotak penampung fluida.

- Termostat berfungsi untuk mengatur berapa panas yang akan diberikan kepada air yang akan digunakan sebagai fluida pemanas di dalam penelitian ini.

- Pompa Pompa digunakan untuk mengalirkan fluida panas di dalam alat penukar kalor sedangkan fluida dingin dialirkan melalui keran yang terdapat di dekat apk.

\subsection{Bahan}

Bahan yang digunakan pada penelitian ini adalah Plat besi yang digunakan sebagai tempat menampung fluida panas, fluida buangan, dan fluida dingin.

- Besi segi empat yang digunakan sebagai rangka alat penukar kalor .

- Pipa tembaga sebagai tempat mengalirnya fluida

- Flow meter yang digunakan untuk mengukur kecepatan aliran air dalam satuan liter / menit ataupun galon per menit

- Stop Keran (Ball Valve yang digunakan sebagai pemutus atau penyambung aliran fluida. 
- Pompa sentrifugal digunakan untuk mengalirkan fluida saat pengujian kinerja alat penukar kalor.

- Pipa Besi digunakan sebagai tempat mengalirnya fluida panas dan .

- Pipa Fitting Besi

Dimana pipe ini digunakan untuk menyambung pipa pada bagian ujung belokan dua arah.

\subsection{Skema Uji Alat Penukar Kalor}

Skema pengujian untuk mendapatkan kinerja dari alat penukar kalor tipe shell and tube satu cangkang dua laluan sebagai pemanas air adalah sebagai berikut.

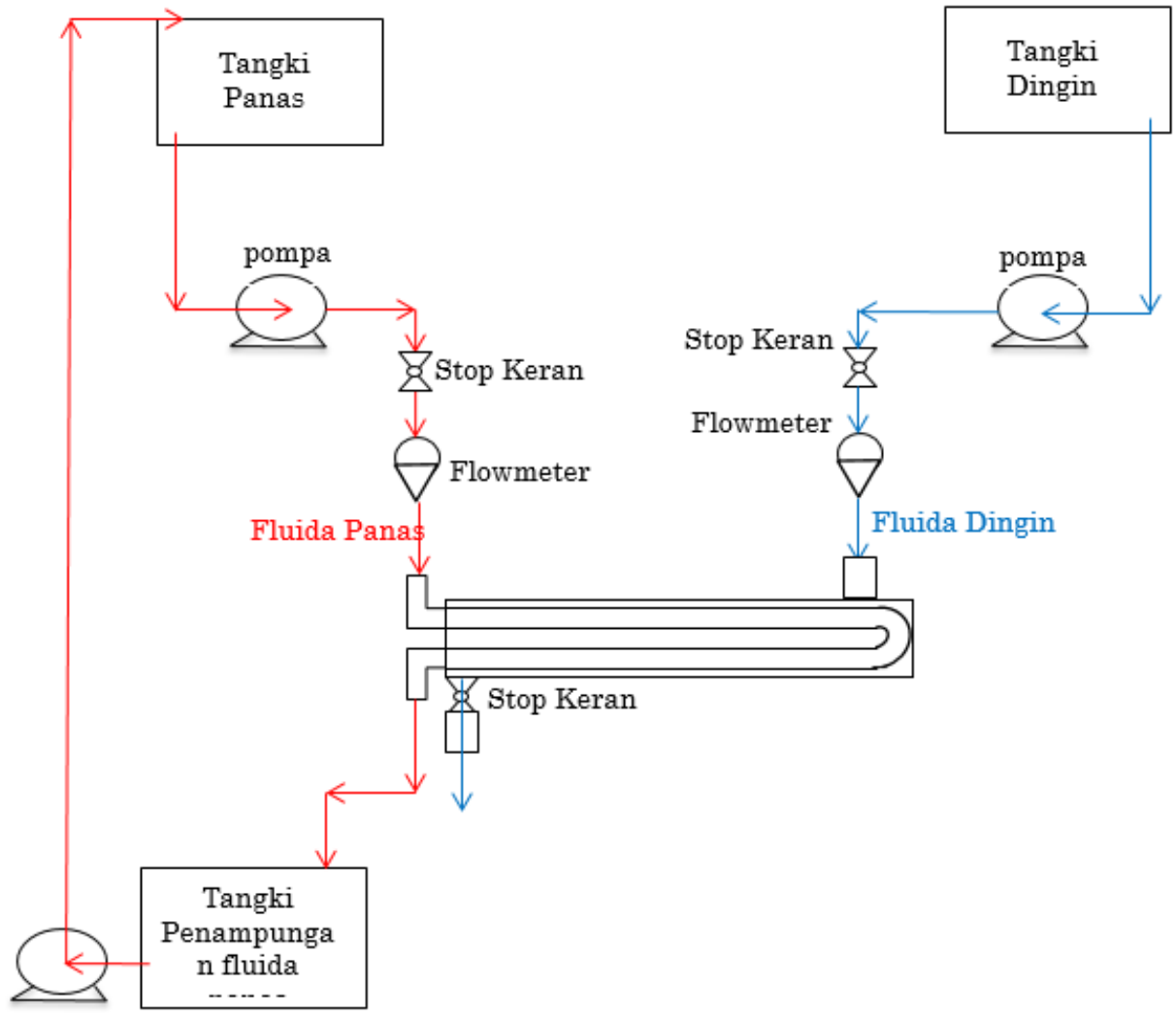

Gambar 3.2 Skema pengujian

\subsection{Prosedur Percobaan}

Proses pengujian terdiri dari beberapa langkah-langkah yaitu sebagai berikut :

- Memasukkan fluida ke dalam tangki persedian .

- Masukkan fluida (air) ke dalam tangki air panas dan tangki air dingin, kedua tangki tersebut diisi sampai melimpah.

- Jalankan pompa sirkulasi air panas dan sirkulasi air panas.

- Keluarkan (vent) semua udara dari jalur pipa.

- Periksa alat pemanas listrik dengan saklar pada on. 
- Atur katup sesuai dengan kapasitas aliran yaitu 108 1/j, 180 1/j, 300 1/j, 510 1/j. Atur thermostat sebesar $40^{\circ} \mathrm{C}$ untuk menentukan suhu fluida panas.

- Catat data suhu keluaran jalur pipa dingin yang dapat dilihat pada instrument alat ukur suhu.

- Ulangi kembali untuk suhu masukan fluida panas yaitu $50^{\circ} \mathrm{C}$, dan $60^{\circ} \mathrm{C}$.

\section{Hasil Dan Pembahasan}

Untuk perhitungan secara teori dengan metode NTU, proses perhitungannya ditampilkan berikut ini untuk kondisi satu titik. Hasil perhitungan secara menyeluruh akan ditampilkan dalam bentuk tabel. Temperatur fluida panas masuk $\left(T_{h, i}\right) 40{ }^{\circ} \mathrm{C}$ dan temperatur fluida dingin masuk $\left(T_{c, i}\right) 29^{\circ} \mathrm{C}$ pada debit masuk fluida panas $510 \mathrm{l} / \mathrm{jam}$ dan debit masuk fluida dingin $108 \mathrm{l} / \mathrm{jam}$. Fluida yang dianalisis sebagai fluida panas dan fluida dingin adalah air.

Pada APK terdapat 1 cangkang dan 2 laluan pipa dalam. Diameter pipa cangkang dan pipa dalam APK adalah $70 \mathrm{~mm}$ dan $12 \mathrm{~mm}$. Panjang dari pipa cangkang adalah $1.35 \mathrm{~m}$ sedangkan panjang laluan pipa dalam adalah $2.7 \mathrm{~m}$

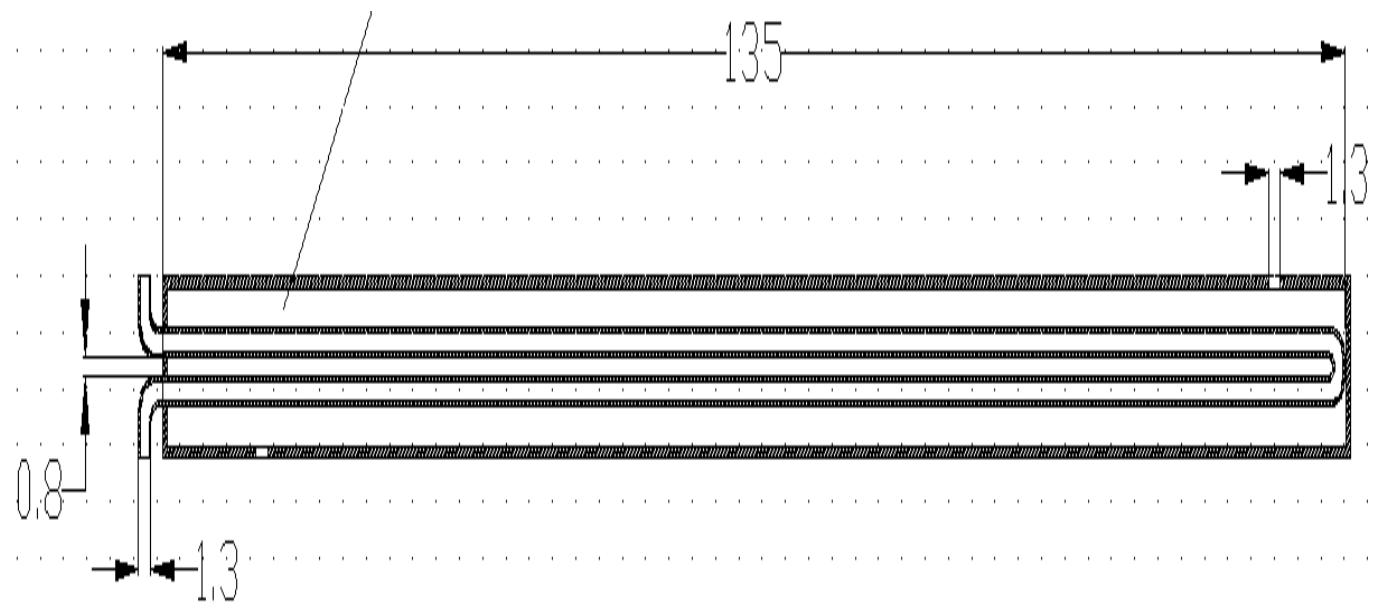

Gambar 4.1 Dimensi APK shell \& tube

Hasil perhitungan secara teori dengan menyeluruh dapat dilihat pada tabel berikut :

Tabel 4.1 Efektifitas APK Secara Teori (Metode NTU)

\begin{tabular}{|c|c|c|c|c|c|c|}
\hline $\begin{array}{l}\text { Kapasitas } \\
\text { aliran air } \\
\text { panas }(l / \text { jam })\end{array}$ & $\begin{array}{l}\text { Kapasitas } \\
\text { aliran air } \\
\text { dingin }(l / \mathrm{jam})\end{array}$ & $T_{h, i}\left({ }^{\circ} \mathrm{C}\right)$ & $T_{c, i}\left({ }^{\circ} \mathrm{C}\right)$ & $T_{h, o}\left({ }^{\circ} \mathrm{C}\right)$ & $T_{c, o}\left({ }^{\circ} \mathrm{C}\right)$ & $\varepsilon(\%)$ \\
\hline \multirow{3}{*}{510} & \multirow{3}{*}{108} & 40 & 29 & 37.7378 & 31.2621 & 96.54313 \\
\hline & & 50 & 29 & 45.6812 & 33.3187 & 96.54315 \\
\hline & & 60 & 29 & 53.6030 & 35.3969 & 96.56460 \\
\hline \multirow{3}{*}{510} & \multirow{3}{*}{180} & 40 & 29 & 36.5911 & 32.4088 & 87.58169 \\
\hline & & 50 & 29 & 43.4904 & 35.5095 & 87.38394 \\
\hline & & 60 & 29 & 50.3670 & 38.6329 & 87.35387 \\
\hline \multirow{3}{*}{510} & \multirow{3}{*}{300} & 40 & 29 & 35.0891 & 33.9108 & 75.74132 \\
\hline & & 50 & 29 & 40.6099 & 38.3901 & 75.70823 \\
\hline & & 60 & 29 & 46.1145 & 42.8854 & 75.66885 \\
\hline
\end{tabular}


Dari perhitungan teori dengan metode NTU diperoleh efektifitas APK minimum adalah $75.70823 \%$ pada temperatur fluida panas masuk $\left(T_{h, i}\right) 50{ }^{\circ} \mathrm{C}$ dan temperatur fluida dingin masuk $\left(T_{c, i}\right) 29{ }^{\circ} \mathrm{C}$ pada debit masuk fluida panas $510 \mathrm{l} / \mathrm{jam}$ dan debit masuk fluida dingin $300 \mathrm{l} / \mathrm{jam}$. Sedangkan efektifitas APK maksimum adalah $96.56460 \%$ pada temperatur fluida panas masuk $\left(T_{h, i}\right) 60^{\circ} \mathrm{C}$ dan temperatur fluida dingin masuk $\left(T_{c, i}\right) 29{ }^{\circ} \mathrm{C}$ pada debit masuk fluida panas $510 \mathrm{l} / \mathrm{jam}$ dan debit masuk fluida dingin $108 \mathrm{l} / \mathrm{jam}$.

Dari tabel diatas dapat dibuat perbandingan efektifitas APK pada tiga debit aliran fluida dingin berbeda. Berikut ini adalah grafik - grafik efektifitas APK perhitungan teori pada kapasistas aliran fluida dingin 108 1/j, 180 1/j, 300 l/j

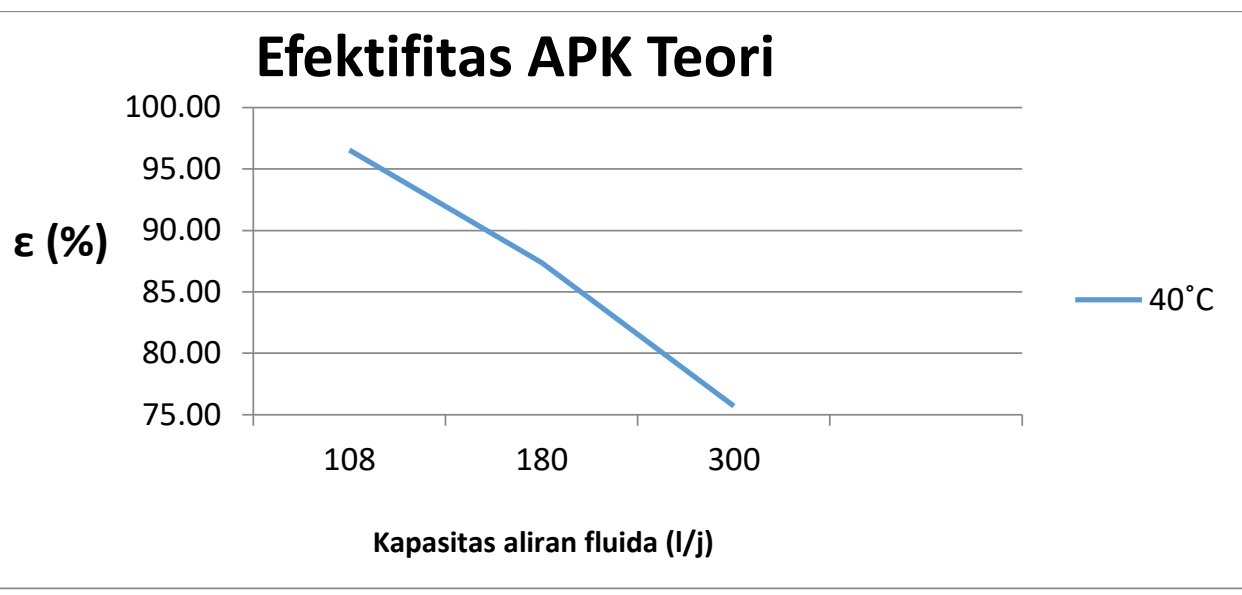

Gambar 4.2 Grafik efektifitas teori aliran fluida panas pada suhu $40^{\circ} \mathrm{C}$ kapasitas aliran fluida dingin 108 1/j, 180 1/j dan 300 1/j

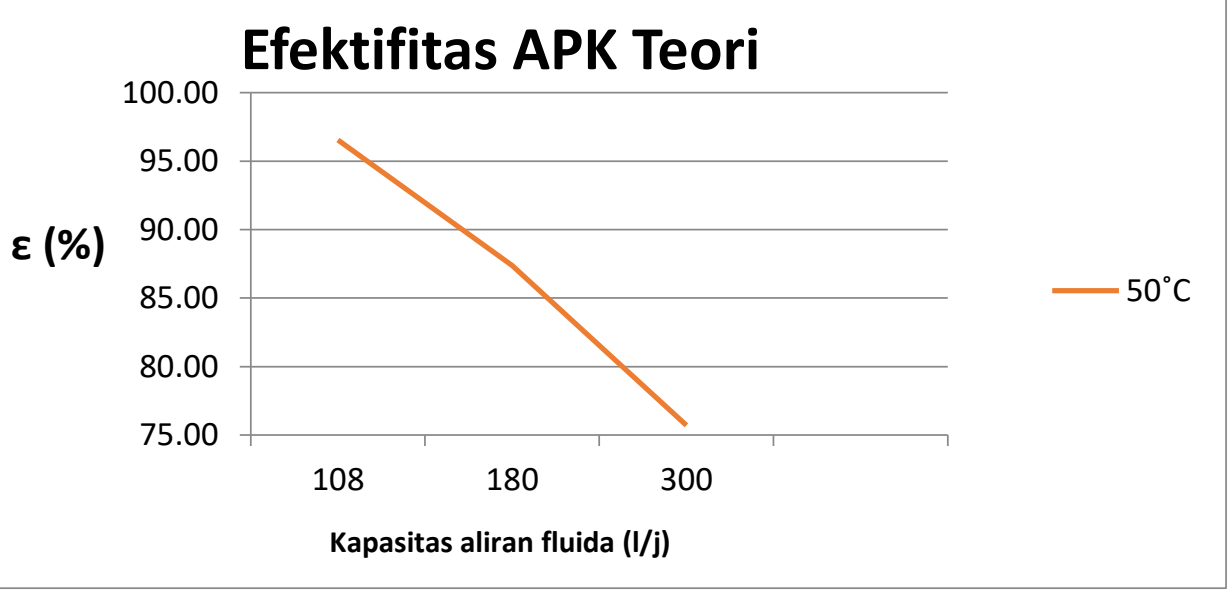

Gambar 4.3 Grafik efektifitas teori aliran fluida panas pada suhu $50^{\circ} \mathrm{C}$ kapasitas aliran fluida dingin 108 1/j , 180 1/j dan 300 1/j 


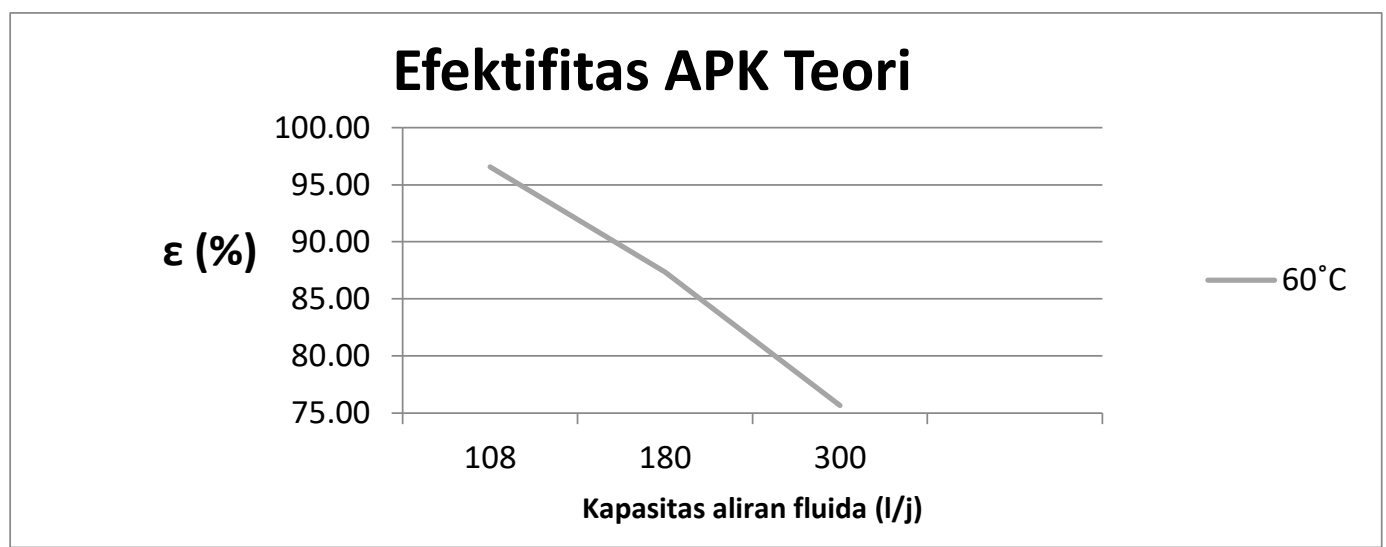

Gambar 4.4 Grafik efektifitas teori aliran fluida panas pada suhu $60^{\circ} \mathrm{C}$ kapasitas aliran fluida dingin 108 1/j , 180 1/j dan 300 1/j

Pada grafik diatas, didapatkan bahwa seiring bertambahnya kapasitas aliran fluida maka efektifitas yang didapatkan juga semakin menurun. $\varepsilon$ tertinggi didapatkan pada kapasitas aliran fluida panas sebesar $108 \mathrm{l} / \mathrm{j}$ dengan suhu fluida panas $60^{\circ} \mathrm{C}$.

Tabel 4.2 Efektifitas APK di Lapangan

\begin{tabular}{|c|c|c|c|c|c|c|}
\hline $\begin{array}{l}\text { Kapasitas aliran } \\
\text { air panas }(l / \text { jam })\end{array}$ & $\begin{array}{l}\text { Kapasitas aliran } \\
\text { air dingin } \\
(l / \text { jam })\end{array}$ & $T_{h, i}\left({ }^{\circ} \mathrm{C}\right)$ & $T_{c, i}\left({ }^{\circ} \mathrm{C}\right)$ & $T_{h, o}\left({ }^{\circ} \mathrm{C}\right)$ & $T_{c, o}\left({ }^{\circ} \mathrm{C}\right)$ & $\varepsilon(\%)$ \\
\hline \multirow{3}{*}{510} & \multirow{3}{*}{108} & 39.6818 & 28.2090 & 39.1727 & 36.8545 & 30.1901 \\
\hline & & 49.4272 & 29.9636 & 48.8636 & 32,8268 & 35.4040 \\
\hline & & 59.6090 & 30.3545 & 58.5545 & 40.3909 & 34.3070 \\
\hline \multirow{3}{*}{510} & \multirow{3}{*}{180} & 39.6636 & 28.3545 & 39.1545 & 30.7090 & 20.8199 \\
\hline & & 49.3818 & 29.9818 & 48.7909 & 33.7181 & 19.2596 \\
\hline & & 59.5818 & 29.9636 & 58.5818 & 35.3545 & 18.2013 \\
\hline \multirow{3}{*}{510} & \multirow{3}{*}{300} & 39.6909 & 28.2090 & 39.0272 & 29.7363 & 13.3016 \\
\hline & & 49.5545 & 28.7272 & 49.0818 & 31.6909 & 14.2295 \\
\hline & & 59.5727 & 31.0636 & 58.5454 & 34.6272 & 12.5 \\
\hline
\end{tabular}

Dari perhitungan data di lapangan diperoleh efektifitas APK minimum adalah $12.5 \%$ pada temperatur fluida panas masuk $\left(T_{h, i}\right) 59.5727{ }^{\circ} \mathrm{C}$ dan temperatur fluida dingin masuk $\left(T_{c, i}\right) 31.0636{ }^{\circ} \mathrm{C}$ pada debit masuk fluida panas $510 \mathrm{l} / \mathrm{jam}$ dan debit masuk fluida dingin $300 \mathrm{l} / \mathrm{jam}$. Sedangkan efektifitas APK maksimum adalah $35.4040 \%$ pada temperatur fluida panas masuk $\left(T_{h, i}\right) 49.4272{ }^{\circ} \mathrm{C}$ dan temperatur fluida dingin masuk $\left(T_{c, i}\right) 30.3545{ }^{\circ} \mathrm{C}$ pada debit masuk fluida panas $510 \mathrm{l} / \mathrm{jam}$ dan debit masuk fluida dingin $108 \mathrm{l} / \mathrm{jam}$.

Dari perhitungan secara menyeluruh yang telah ditampilkan diatas dapat dilihat bahwa perhitungan efektifitas APK secara teori metode NTU lebih tinggi dibandingkan dengan perhitungan efektifitas APK pada lapangan 


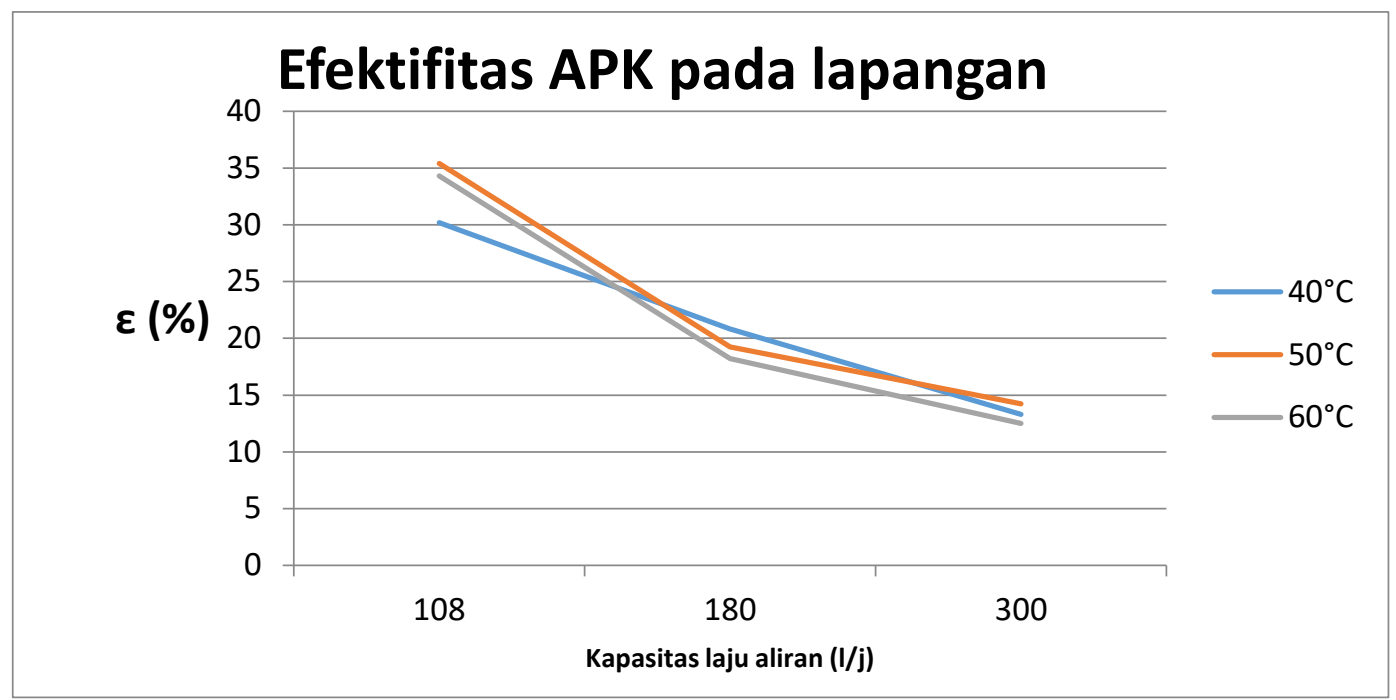

Gambar 4.5 Grafik perbandingan efektifitas lapangan aliran fluida panas variasi 3 suhu pada kapasitas aliran fluida dingin 108 1/j, 180 l/j dan $3001 / j$.

Dari ketiga grafik diatas dapat dilihat kemiringan grafik efektifitas APK hampir mirip dimana efektifitas APK cenderung menurun . Pada grafik kedua terdapat efektifitas APK maksimum yaitu $35.4040 \%$ pada temperatur fluida panas masuk $\left(T_{h, i}\right) 50{ }^{\circ} \mathrm{C}$ dan temperatur fluida dingin masuk $\left(T_{c, i}\right) 29^{\circ} \mathrm{C}$ pada debit masuk fluida panas $510 \mathrm{l} / \mathrm{jam}$ dan debit masuk fluida dingin $180 \mathrm{l} / \mathrm{jam}$.

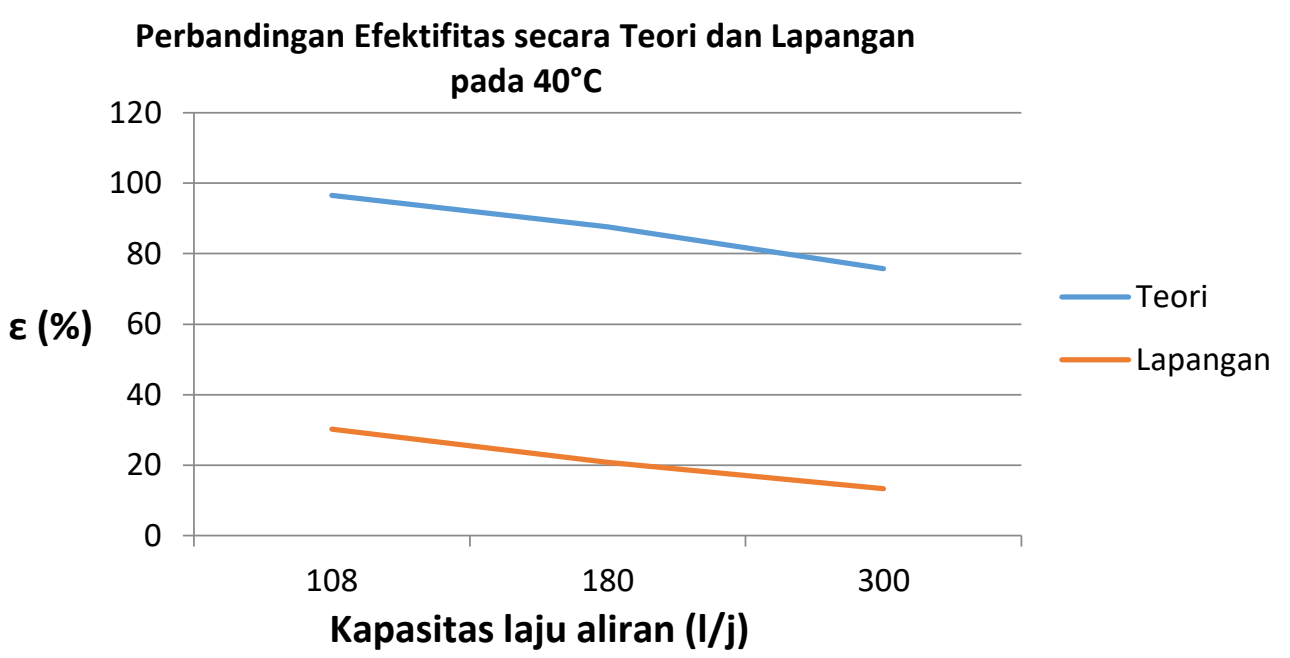

Gambar 4.6 Grafik perbandingan efektifitas secara teori dan lapangan pada suhu $40^{\circ} \mathrm{C}$ 


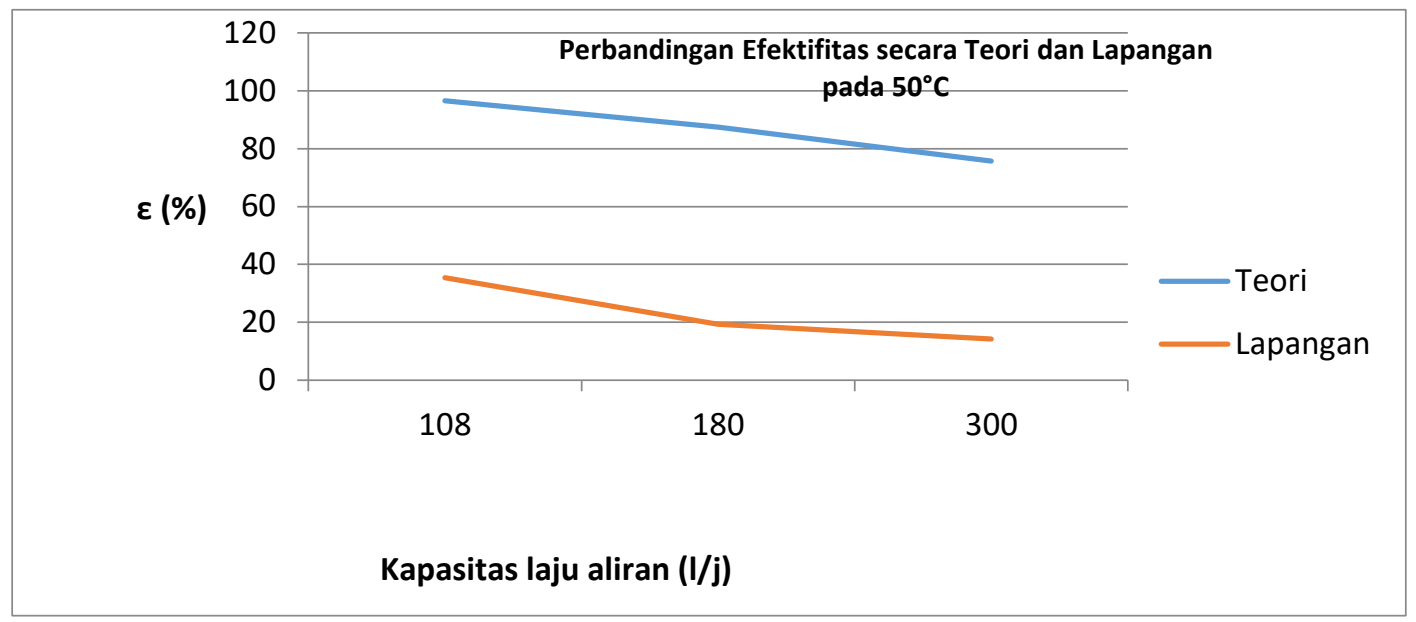

Gambar 4.7 Grafik perbandingan efektifitas secara teori dan lapangan pada suhu $50^{\circ} \mathrm{C}$

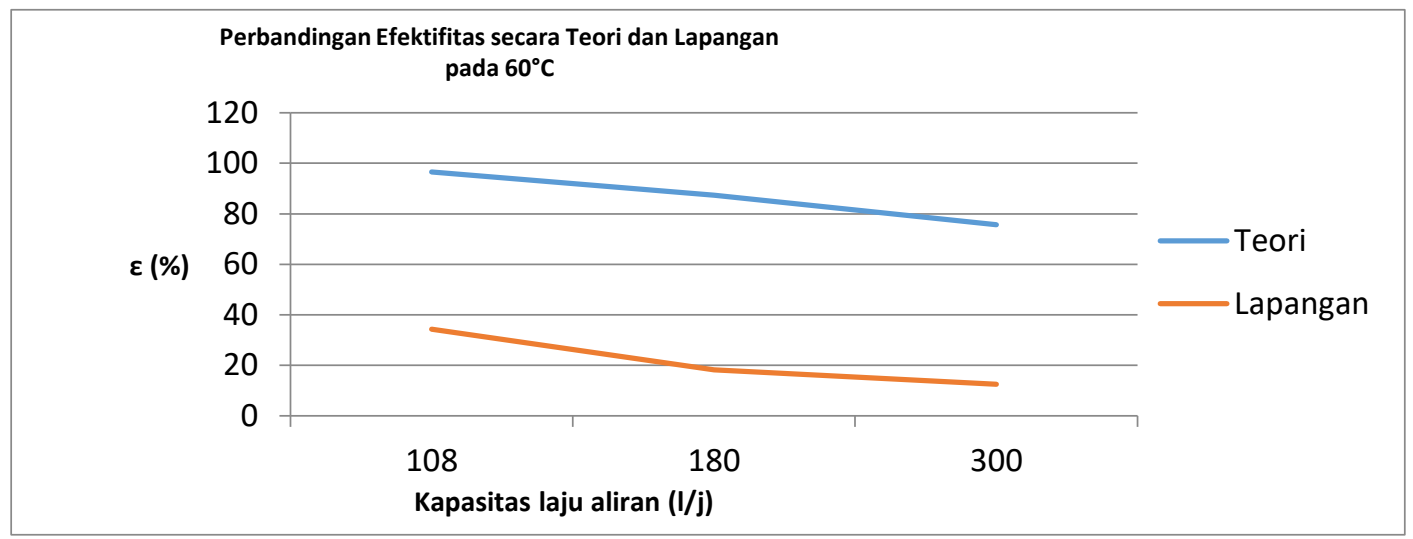

Gambar 4.8 Grafik perbandingan efektifitas secara teori dan lapangan pada suhu $60^{\circ} \mathrm{C}$

Dari ketiga grafik dapat dilihat bahwa efektifitas yang didapatkan secara teori jauh lebih tinggi dibandingkan efektifitas yang didapatkan pada lapangan dikarenakan isolasi pada tabung apk yang masih kurang sempurna sehingga masih bisa terjadi heat loss pada apk tersebut. Adapun penyebab lain yaitu panas pada tabung apk dapat berpindah pada pipa masukan dari fluida dingin, hal tersebut menyebabkan pencatatan data yang kurang akurat sehingga menyebabkan nilai efektifitas yang kurang bagus apabila dibandingkan dengan nilai efektifitas secara teori (metode NTU)

Dari perhitungan data di lapangan oleh tim riset sebelumnya dengan APK tabung sepusat diperoleh efektifitas APK minimum adalah $4,62875 \%$ pada temperatur fluida panas masuk $\left(T_{h, i}\right) 40{ }^{\circ} \mathrm{C}$ dan temperatur fluida dingin masuk $\left(T_{c, i}\right)$ $30^{\circ} \mathrm{C}$ pada debit masuk fluida panas $180 \mathrm{l} / \mathrm{jam}$ dan debit masuk fluida dingin $180 \mathrm{l} / \mathrm{jam}$. Sedangkan efektifitas APK maksimum adalah $31,00435 \%$ pada temperatur fluida panas masuk $\left(T_{h, i}\right) 55{ }^{\circ} \mathrm{C}$ dan temperatur fluida dingin masuk $\left(T_{c, i}\right) 32{ }^{\circ} \mathrm{C}$ pada debit masuk fluida panas $180 \mathrm{l} / \mathrm{jam}$ dan debit masuk fluida dingin $420 \mathrm{l} / \mathrm{jam}$. Perhitungan data pada APK shell \& tube didapatkan nilaiefektifitas APK maksimum yaitu $35.4040 \%$ pada temperatur fluida panas masuk $\left(T_{h, i}\right) 50{ }^{\circ} \mathrm{C}$ dan temperatur fluida dingin masuk $\left(T_{c, i}\right) 32{ }^{\circ} \mathrm{C}$ pada debit masuk fluida panas $510 \mathrm{l} / \mathrm{jam}$ dan debit masuk fluida dingin $180 \mathrm{l} / \mathrm{jam}$. Dari hasil yang di peroleh apabila dibandingkan, nilai efektifitas terdapat perbedaan yang cukup signifikan, hal tersebut dikarenakan pada tabung dalam yang digunakan adalah pipa tembaga yang memiliki nilai konduktivitas, yaitu $385 \mathrm{~W} / \mathrm{mKdimana}$ nilai tersebut adalah cukup tinggi dibandingkan dengan nilai konduktivtas pipa aluminium yaitu $205 \mathrm{~W} / \mathrm{mK}$ 


\subsection{Analisa Pada Pengujian II}

Untuk perhitungan secara teori digunakan metode NTU dan hasil perhitungan secara menyeluruh akan ditampilkan dalam bentuk tabel. Temperatur fluida panas masuk $\left(T_{h, i}\right) 40^{\circ} \mathrm{C}, 50^{\circ} \mathrm{C}, 60^{\circ} \mathrm{C}$ dan temperatur fluida dingin masuk $\left(T_{c, i}\right) 28^{\circ} \mathrm{C}$ pada debit masuk fluida panas $510 \mathrm{l} / \mathrm{jam}$ dan variasi debit masuk fluida dingin $108 \mathrm{l} / \mathrm{jam}, 180 \mathrm{l} / \mathrm{jam}$, $300 \mathrm{l} / \mathrm{jam}$. Fluida yang dianalisis sebagai fluida panas adalah air dan fluida dingin adalah methanol.

Dari hasil perhitungan

- Th yang didapat $=(50+47.7986) / 2=48.8993^{\circ} \mathrm{C}$ tidak sama dengan pemisalan $50^{\circ} \mathrm{C}$

- Tc yang didapat $=(28+30.2014) / 2=29.1007^{\circ} \mathrm{C}$ tidak sama dengan pemisalan $28^{\circ} \mathrm{C}$

Untuk hasil dari iterasi selanjutnya pada tiap kondisi dikerjakan pada program microsoft excel dan hasil dari iterasi tersebut dapat dilihat pada tabel berikut beserta data keefektifitasannya.

Berikut merupakan lampiran tabel perhitungan teori dengan laju aliran fluida panas $510 \mathrm{~L} / \mathrm{jam}$ dan variasi laju aliran fluida dingin $108,180,300 \mathrm{~L} / \mathrm{jam}$.

Tabel 4.4 hasil perhitungan berdasarkan metode iterasi

\begin{tabular}{|c|c|c|c|c|c|c|c|}
\hline \multicolumn{5}{|c|}{ DATA TEORI } & \multicolumn{2}{|c|}{ Hasil Teori } & \multirow[b]{2}{*}{$\begin{array}{l}\text { Efektifitas teori } \\
(\%)\end{array}$} \\
\hline $\begin{array}{l}\text { Kondisi } \\
\text { eksperimen }\end{array}$ & $\begin{array}{l}\text { Thi } \\
\left({ }^{\circ} \mathrm{C}\right)\end{array}$ & $\mathrm{Qh}(1 / \mathrm{j})$ & $\begin{array}{l}\text { Tci } \\
\left({ }^{\circ} \mathrm{C}\right)\end{array}$ & $\begin{array}{l}\text { Qc } \\
(1 / j)\end{array}$ & Tho $\left({ }^{\circ} \mathrm{C}\right)$ & $\operatorname{Tco}\left({ }^{\circ} \mathrm{C}\right)$ & \\
\hline 1 & \multirow{3}{*}{40} & \multirow{3}{*}{510} & \multirow{3}{*}{28} & 108 & 38.8037 & 29.1963 & 97.396 \\
\hline 2 & & & & 180 & 38.0923 & 29.9077 & 93.1619 \\
\hline 3 & & & & 300 & 37.0259 & 30.9741 & 87.1023 \\
\hline 1 & \multirow{3}{*}{50} & \multirow{3}{*}{510} & \multirow{3}{*}{28} & 108 & 47.7986 & 30.2014 & 97.3743 \\
\hline 2 & & & & 180 & 46.4891 & 31.5109 & 93.1245 \\
\hline 3 & & & & 300 & 44.5259 & 33.4741 & 87.0366 \\
\hline 1 & \multirow{3}{*}{60} & \multirow{3}{*}{510} & \multirow{3}{*}{28} & 108 & 56.7845 & 31.2155 & 97.3497 \\
\hline 2 & & & & 180 & 54.87076 & 33.12924 & 93.08144 \\
\hline 3 & & & & 300 & 52.00108 & 35.99892 & 87.02052 \\
\hline
\end{tabular}

Dan data keefektifitasan dapat dilihat juga dalam grafik seperti di bawah ini, 


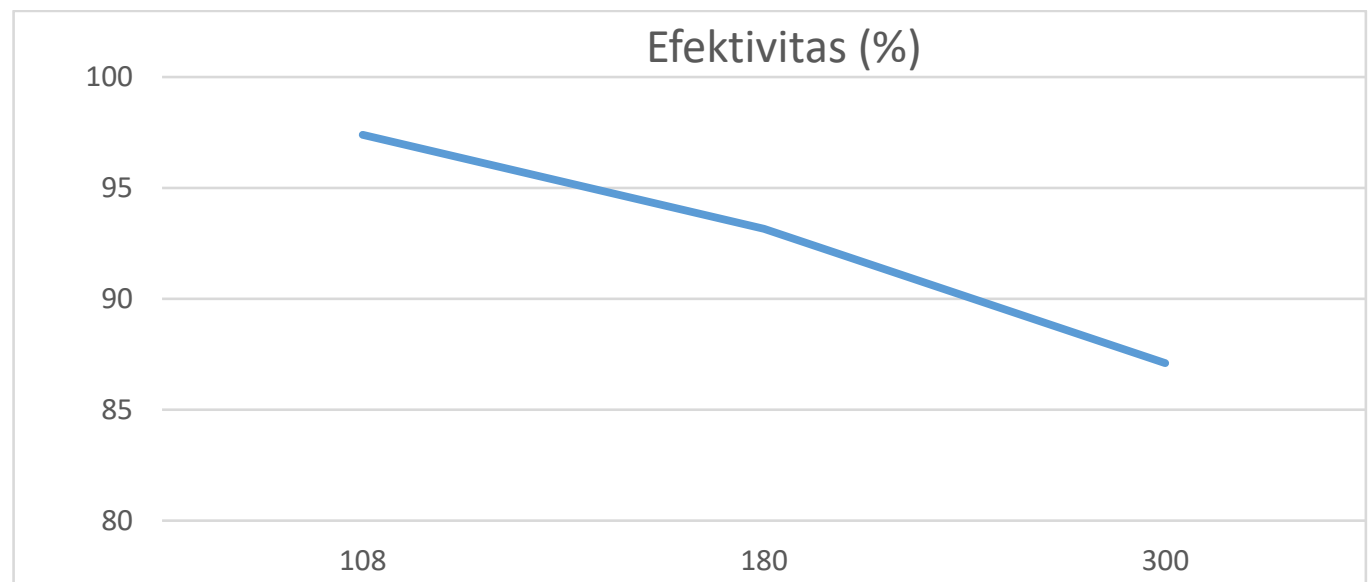

Gambar 4.9 grafik efektifitas perhitungan teori (kapasitas fluida panas $510 \mathrm{~L} / \mathrm{j}$ dengan suhu fluida panas $40^{\circ} \mathrm{C}$ )

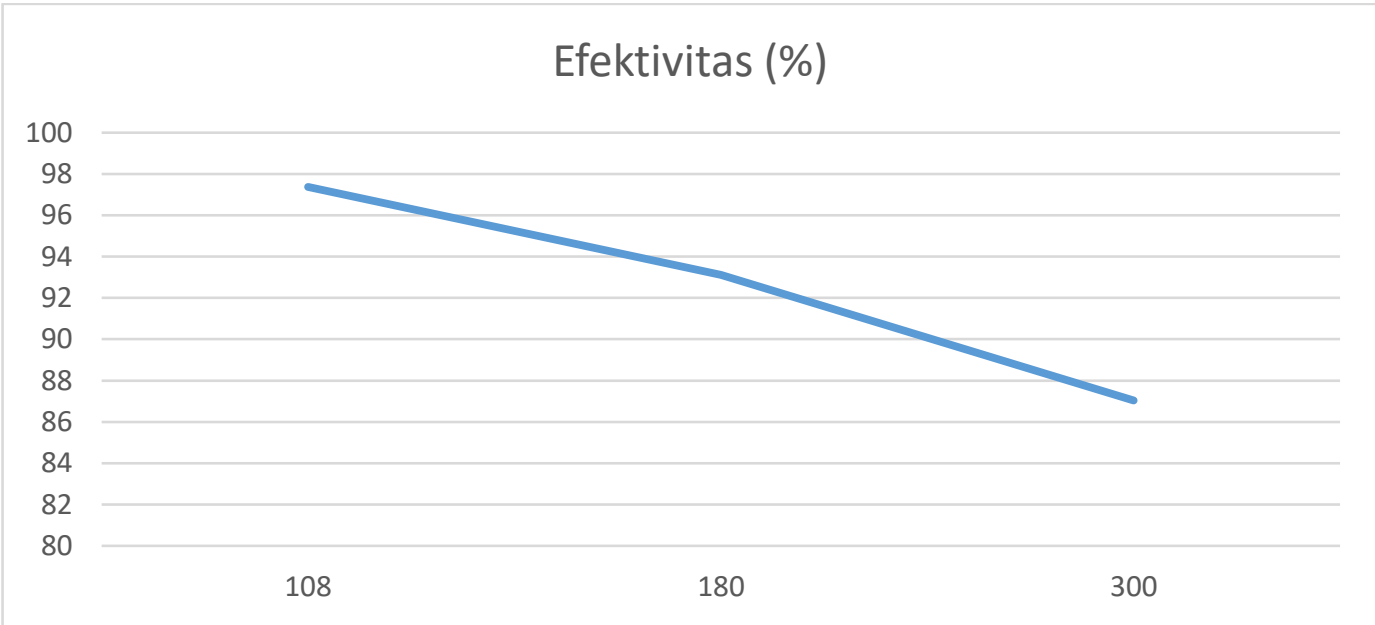

Gambar 4.10 grafik efektifitas perhitungan teori (kapasitas fluida panas $510 \mathrm{~L} / \mathrm{j}$ dengan suhu fluida panas $50^{\circ} \mathrm{C}$ )

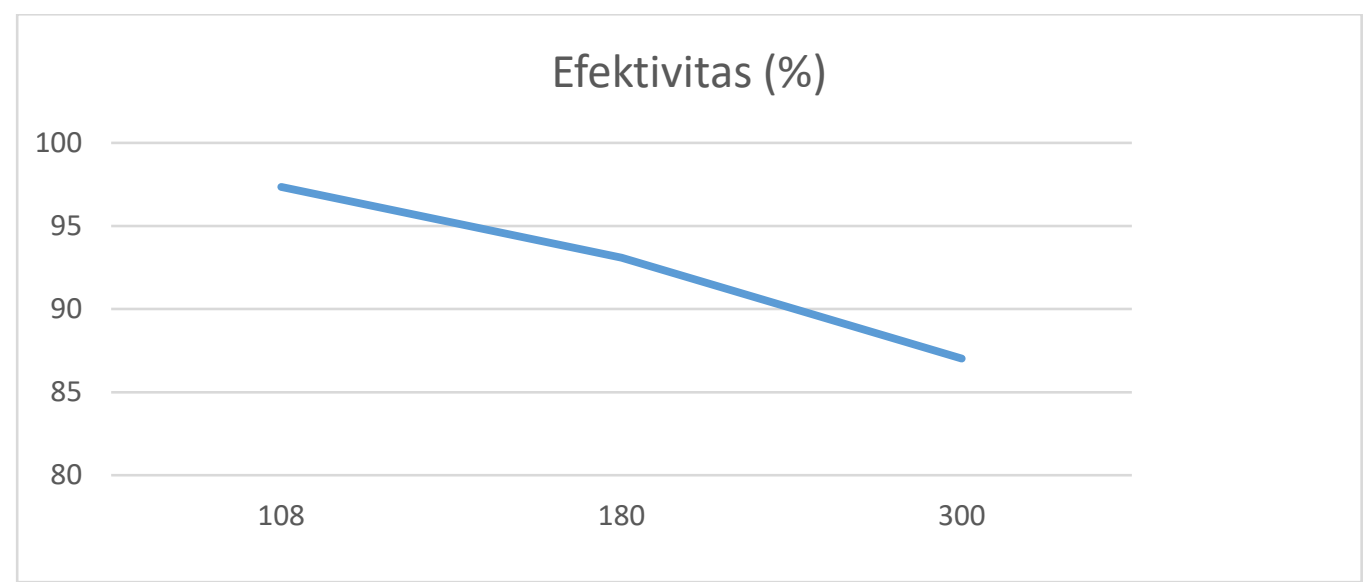

Gambar 4.11 grafik efektifitas perhitungan teori (kapasitas fluida panas $510 \mathrm{~L} / \mathrm{j}$ dengan suhu fluida panas $60^{\circ} \mathrm{C}$ ) 
Pada grafik diatas dapat disimpulkan bahwa seiring bertambahnya kapasitas laju aliran fluida dingin maka efektivitas alat penukar kalor shell and tube ini semakin menurun.

Adapun data hasil pengujian yang telah dilakukan pada APK shell and tube dapat dilihat dibawah ini , dimana kapasitas aliran fluida panas yaitu yang mengalir di dalam tabung dalam (shell) adalah $510 \mathrm{~L} / \mathrm{j}$. Kemudian untuk fluida dingin yaitu air yang mengalir didalam tabung (tube)adalah $108 \mathrm{~L} / \mathrm{j}, 180 \mathrm{~L} / \mathrm{j}$ dan $300 \mathrm{~L} / \mathrm{j}$.

Data hasil percobaan tersebut kemudia diolah untuk mendapatkan keefektifitasan hasil pengujian. Dimana rumus efektifitas yaitu,

$$
\begin{gathered}
\mathrm{E}=\frac{T_{h i}-T_{h o}}{T_{c o}-T_{c i}}, \text { bila }\left(\dot{\mathrm{m}} \cdot \mathrm{C}_{\mathrm{p}}\right) \min =\dot{\mathrm{m}}_{\mathrm{h}} \cdot \mathrm{C}_{\mathrm{ph}} \\
\text { dan } \\
\mathrm{E}=\frac{T_{c o}-T_{c i}}{T_{h i}-T_{h o}}, \text { bila }\left(\dot{\mathrm{m}} \cdot \mathrm{C}_{\mathrm{p}}\right) \min =\dot{\mathrm{m}}_{\mathrm{c}} \cdot \mathrm{C}_{\mathrm{pc}}
\end{gathered}
$$

Nilai dari $\left(\dot{m} . \mathrm{C}_{\mathrm{p}}\right)$ min dicari untuk menentukan rumus efektifitas yang akan digunakan.

Dikarenakan nilai dari Cc dari methanol yang jauh lebih rendah dari nilai Ch dari air maka nilai dari Cc selalu menjadi nilai Cmin.

Sehingga didapatkan grafik efektifitas untuk tia $\mathrm{p}$ kondisi yaitu sebagai berikut

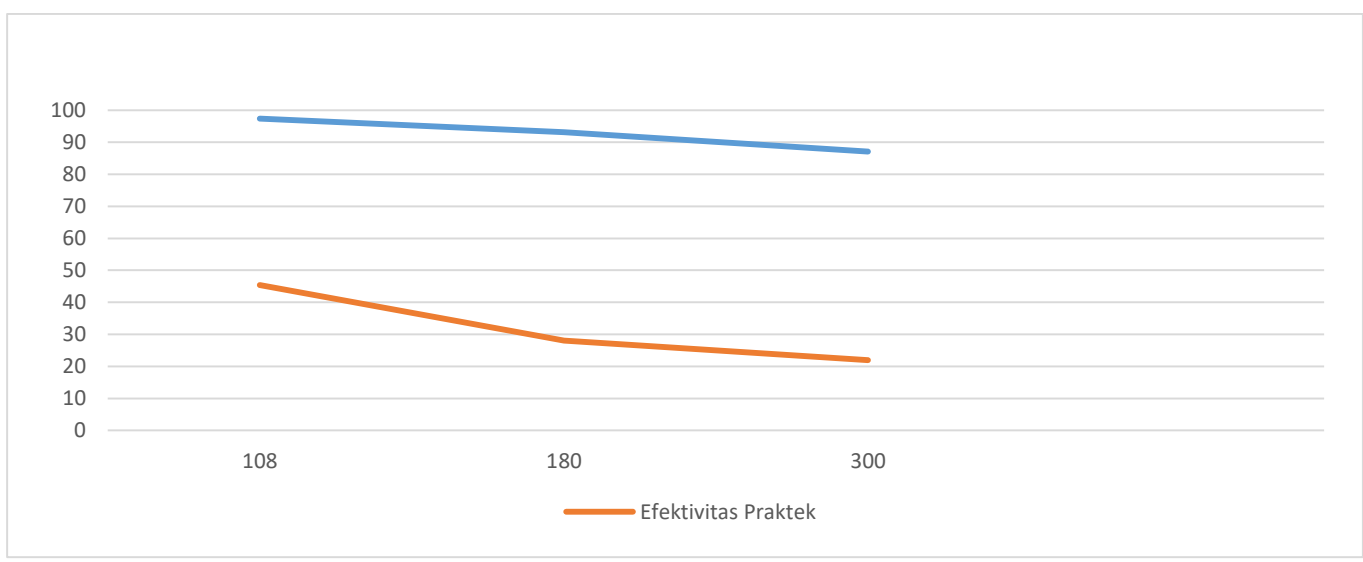

Gambar 4.12 grafik efektifitas percobaan (kapasitas fluida panas $510 \mathrm{~L} / \mathrm{j}$ dengan suhu fluida panas $40^{\circ} \mathrm{C}$ )

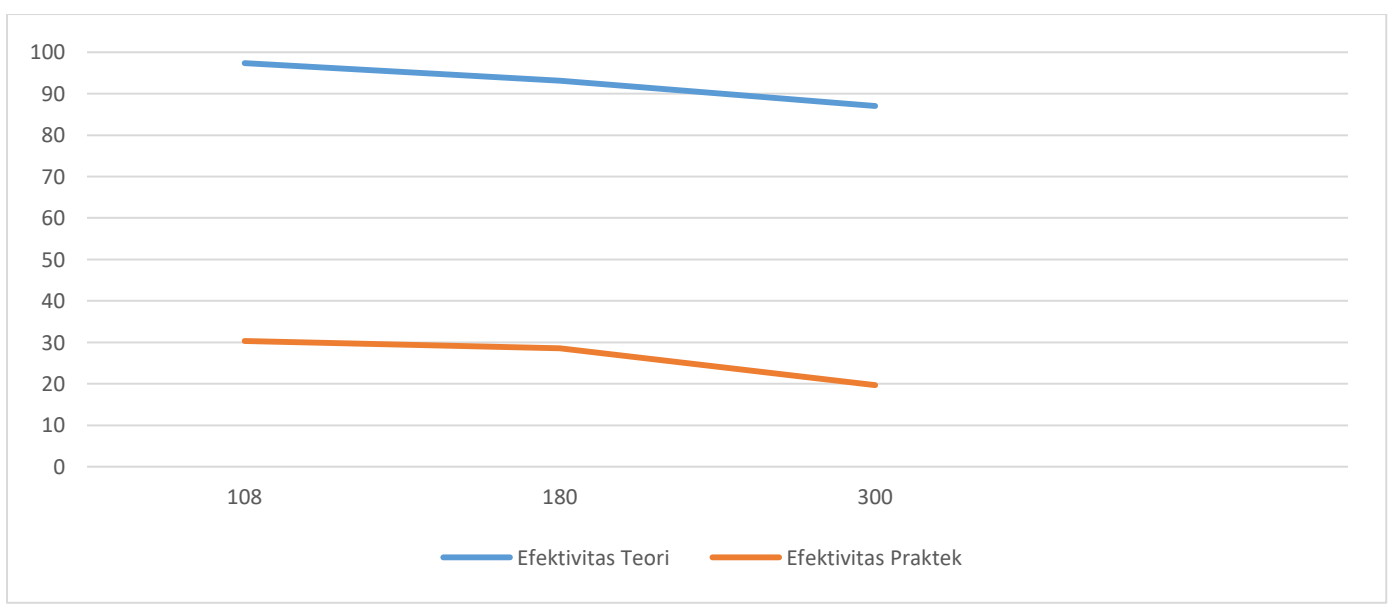

Gambar 4.13 grafik efektifitas percobaan (kapasitas fluida panas $510 \mathrm{~L} / \mathrm{j}$ dengan suhu fluida panas $50^{\circ} \mathrm{C}$ ) 


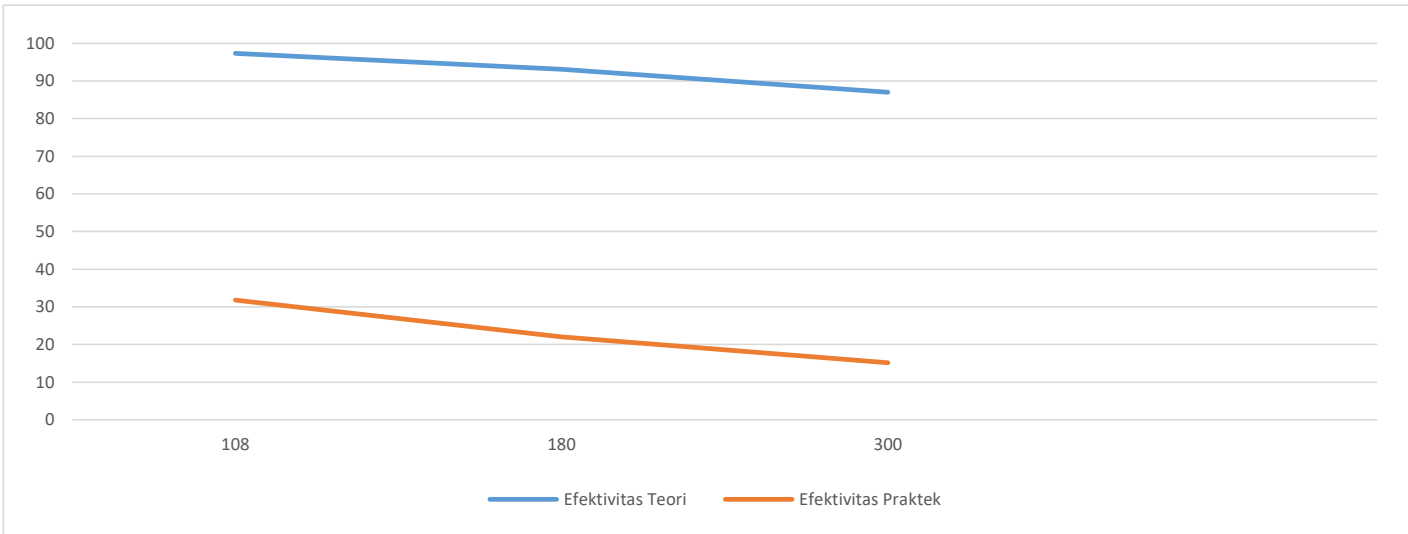

Gambar 4.14 grafik efektifitas percobaan (kapasitas fluida panas $510 \mathrm{~L} / \mathrm{j}$ dengan suhu fluida panas $60^{\circ} \mathrm{C}$ )

Berikut adalah tabel perbandingan antara hasil teori (Metode NTU) dengan hasil yang didapat pada eksperimen (Hasil Pengujian) :

Dari tabel di atas dapat dilihat bahwa perbedaan efektivitas teori dengan efektivitas praktek sangat besar. Hal ini disebabkan ada beberapa faktor yang menyebabkan efektivitas teori sangat rendah seperti panas yang keluar (heat loss) pada alat penukar kalor shell and tube karena isolasi yang tidak sempurna dan faktor cuaca .

Adapun data hasil pengujian yang telah dilakukan pada tim sebelumnya tentang APK tabung sepusat (annulus) dapat dilihat dibawah ini , dimana variasi yang dibuat yaitu kapasitas aliran fluida panas yaitu yang mengalir di dalam tabung dalam adalah $180 \mathrm{~L} / \mathrm{j}, 240 \mathrm{~L} / \mathrm{j}, 300 \mathrm{~L} / \mathrm{j}$, dan $360 \mathrm{~L} / \mathrm{j}$. Kemudian untuk fluida dingin yaitu air yang mengalir didalam ruang annulus adalah $180 \mathrm{~L} / \mathrm{j}, 240 \mathrm{~L} / \mathrm{j}$ dan $360 \mathrm{~L} / \mathrm{j}$.

Tabel 4.7 Data hasil percobaan APK tabung sepusat (kapasitas fluida dingin $240 \mathrm{~L} / \mathrm{j}$ )

\begin{tabular}{|c|c|c|c|c|c|c|c|}
\hline \multicolumn{5}{|l|}{ Data Teori } & \multicolumn{2}{|c|}{ Hasil eksperimen } & \multirow[b]{2}{*}{ efektifitas $(\%)$} \\
\hline $\begin{array}{l}\text { Kondisi } \\
\text { eksperimen }\end{array}$ & Thi $\left({ }^{\circ} \mathrm{C}\right)$ & Qh $(1 / j)$ & $\begin{array}{l}\text { Tci } \\
\left({ }^{\circ} \mathrm{C}\right)\end{array}$ & $\begin{array}{l}\text { Qc } \\
(1 / j)\end{array}$ & Tho $\left({ }^{\circ} \mathrm{C}\right)$ & $\operatorname{Tco}\left({ }^{\circ} \mathrm{C}\right)$ & \\
\hline 1 & \multirow{4}{*}{40} & 180 & \multirow{4}{*}{34} & \multirow{4}{*}{240} & 39.9150 & 34.7380 & 12.3 \\
\hline 2 & & 240 & & & 39.7000 & 34.7700 & 12.83333333 \\
\hline 3 & & 300 & & & 39.1050 & 34.8630 & 14.38333333 \\
\hline 4 & & 360 & & & 39.0540 & 34.5320 & 8.866666667 \\
\hline 5 & \multirow{4}{*}{45} & 180 & \multirow{4}{*}{35} & \multirow{4}{*}{240} & 42.0250 & 35.7770 & 7.77 \\
\hline 6 & & 240 & & & 41.8720 & 35.5720 & 5.72 \\
\hline 7 & & 300 & & & 42.1980 & 35.7260 & 7.26 \\
\hline 8 & & 360 & & & 42.8490 & 36.0790 & 10.79 \\
\hline 9 & \multirow{3}{*}{50} & 180 & \multirow{3}{*}{36} & \multirow{3}{*}{240} & 46.7270 & 37.6850 & 12.03571429 \\
\hline 10 & & 240 & & & 46.2130 & 37.6700 & 11.92857143 \\
\hline 11 & & 300 & & & 46.9270 & 37.3810 & 9.864285714 \\
\hline
\end{tabular}




\begin{tabular}{|c|c|c|c|c|c|c|c|}
\hline 12 & & 360 & & & 46.8500 & 37.4980 & 10.7 \\
\hline 13 & \multirow{4}{*}{55} & 180 & \multirow{4}{*}{32} & \multirow{4}{*}{240} & 48.3560 & 36.2940 & 18.66956522 \\
\hline 14 & & 240 & & & 47.9600 & 36.4400 & 19.30434783 \\
\hline 15 & & 300 & & & 48.4300 & 36.9840 & 21.66956522 \\
\hline 16 & & 360 & & & 49.0130 & 36.2770 & 18.59565217 \\
\hline
\end{tabular}

Tabel 4.8 Data hasil percobaan APK tabung sepusat (kapasitas fluida dingin $360 \mathrm{~L} / \mathrm{j}$ )

\begin{tabular}{|c|c|c|c|c|c|c|c|}
\hline \multicolumn{5}{|c|}{ DATA TEORI } & \multicolumn{2}{|c|}{ Hasil eksperimen } & \multirow[b]{2}{*}{ efektifitas $(\%)$} \\
\hline $\begin{array}{l}\text { Kondisi } \\
\text { eksperimen }\end{array}$ & Thi $\left({ }^{\circ} \mathrm{C}\right)$ & Qh $(1 / j)$ & Tci $\left({ }^{\circ} \mathrm{C}\right)$ & $\begin{array}{l}\mathrm{Qc} \\
(1 / \mathrm{j})\end{array}$ & Tho $\left({ }^{\circ} \mathrm{C}\right)$ & $\operatorname{Tco}\left({ }^{\circ} \mathrm{C}\right)$ & \\
\hline 1 & \multirow{4}{*}{40} & 180 & \multirow{4}{*}{35} & \multirow{4}{*}{360} & 40.0620 & 35.2100 & 4.2 \\
\hline 2 & & 240 & & & 39.8120 & 35.2940 & 5.88 \\
\hline 3 & & 300 & & & 39.6430 & 35.1090 & 2.18 \\
\hline 4 & & 360 & & & 37.8990 & 35.2870 & 5.74 \\
\hline 5 & \multirow{4}{*}{45} & 180 & \multirow{4}{*}{34} & \multirow{4}{*}{360} & 42.1250 & 34.8230 & 7.481818182 \\
\hline 6 & & 240 & & & 42.1370 & 35.0740 & 9.763636364 \\
\hline 7 & & 300 & & & 42.2270 & 35.0940 & 9.945454545 \\
\hline 8 & & 360 & & & 41.5930 & 35.0480 & 9.527272727 \\
\hline 9 & \multirow{4}{*}{50} & 180 & \multirow{4}{*}{37} & \multirow{4}{*}{360} & 45.9470 & 37.5180 & 3.984615385 \\
\hline 10 & & 240 & & & 47.4490 & 37.6810 & 5.238461538 \\
\hline 11 & & 300 & & & 47.3350 & 38.1720 & 9.015384615 \\
\hline 12 & & 360 & & & 47.3230 & 38.3190 & 10.14615385 \\
\hline 13 & \multirow{4}{*}{55} & 180 & \multirow{4}{*}{9} & \multirow{4}{*}{360} & 47.0300 & 37.5230 & 12.615 \\
\hline 14 & & 240 & & & 47.7020 & 36.8670 & 9.335 \\
\hline 15 & & 300 & & & 47.9320 & 37.0030 & 10.015 \\
\hline 16 & & 360 & & & 48.3560 & 37.2300 & 11.15 \\
\hline
\end{tabular}

Tabel 4.9 Data hasil percobaan APK tabung sepusat (kapasitas fluida dingin $180 \mathrm{~L} / \mathrm{j}$ )

\begin{tabular}{|c|c|c|c|c|c|c|c|}
\hline \multicolumn{5}{|c|}{ DATA TEORI } & \multicolumn{2}{|c|}{ Hasil eksperimen } & \multirow[b]{2}{*}{ efektifitas (\%) } \\
\hline $\begin{array}{l}\text { Kondisi } \\
\text { eksperimen }\end{array}$ & $\begin{array}{l}\text { Thi } \\
\left({ }^{\circ} \mathrm{C}\right)\end{array}$ & $\mathrm{Qh}(1 / \mathrm{j})$ & $\begin{array}{l}\text { Tci } \\
\left({ }^{\circ} \mathrm{C}\right)\end{array}$ & $\begin{array}{l}\mathrm{Qc} \\
(\mathrm{l} / \mathrm{j})\end{array}$ & Tho $\left({ }^{\circ} \mathrm{C}\right)$ & $\operatorname{Tco}\left({ }^{\circ} \mathrm{C}\right)$ & \\
\hline 1 & \multirow{2}{*}{40} & 180 & \multirow{2}{*}{34} & \multirow{2}{*}{180} & 40.9122 & 35.1132 & 18.55333333 \\
\hline 2 & & 240 & & & 39.4511 & 35.2130 & 20.21666667 \\
\hline
\end{tabular}




\begin{tabular}{|c|c|c|c|c|c|c|c|}
\hline 3 & & 300 & & & 39.2911 & 35.1223 & 18.705 \\
\hline 4 & & 360 & & & 39.0235 & 35.0123 & 16.87166667 \\
\hline 5 & \multirow{4}{*}{45} & 180 & \multirow{4}{*}{34} & \multirow{4}{*}{180} & 42.1423 & 34.3432 & 3.12 \\
\hline 6 & & 240 & & & 42.1330 & 35.0521 & 9.564545455 \\
\hline 7 & & 300 & & & 42.0134 & 35.7623 & 16.02090909 \\
\hline 8 & & 360 & & & 42.3421 & 35.3412 & 12.19272727 \\
\hline 9 & \multirow{4}{*}{50} & 180 & \multirow{4}{*}{35} & \multirow{4}{*}{180} & 47.4210 & 37.7710 & 18.47333333 \\
\hline 10 & & 240 & & & 46.7821 & 37.9120 & 19.41333333 \\
\hline 11 & & 300 & & & 46.9660 & 37.4310 & 16.20666667 \\
\hline 12 & & 360 & & & 46.8500 & 37.3112 & 15.408 \\
\hline 13 & \multirow{4}{*}{55} & 180 & \multirow{4}{*}{34} & \multirow{4}{*}{180} & 49.3560 & 35.9940 & 9.495238095 \\
\hline 14 & & 240 & & & 49.1960 & 36.9210 & 13.90952381 \\
\hline 15 & & 300 & & & 48.8210 & 36.5840 & 12.3047619 \\
\hline 16 & & 360 & & & 49.1030 & 36.2170 & 10.55714286 \\
\hline
\end{tabular}

Dari tabel di atas dapat dilihat bahwa rata-rata efektivitas APK shell and tube lebih besar dari APK tabung sepusat , hal ini dapat disebabkan oleh bahan yang digunakan. Bahan yang digunakan pada tabung dalam APK sepusat adalah aluminium dengan nilai konduktivtas pipa aluminium yaitu $205 \mathrm{~W} / \mathrm{mK}$, lebih rendah dari bahan yang digunakan pada pipa alat penukar kalor shell and tube yang memiliki nilai konduktivitas, yaitu $385 \mathrm{~W} / \mathrm{mK}$.

\section{Kesimpulan dan Saran}

\subsection{Kesimpulan}

Kesimpulan yang diperoleh dari perancangan alat penukar kalor tabung sepusat adalah sebagai berikut :

Efektifitas terbesar setelah dilakukan percobaan adalah 35,4040\% 
1. Alat penukar kalor ini berukuran panjang $1,64 \mathrm{~m}$, lebar $0,48 \mathrm{~m}$, dan tinggi 2,1 $\mathrm{m}$, Panjang total pipa pada alat penukar kalornya adalah $2,7 \mathrm{~m}$ berdiameter $13 \mathrm{~mm}$, dan shellnya mempunyai panjang $1,35 \mathrm{~m}$ dan berdiameter 70mm, volume pada tangki Alat penukar ini sebesar 27 Liter.

2. Pada perhitungan data secara teoritis didapatkan efektifitas terbesar pada temperatur fluida panas masuk $\left(T_{h, i}\right)$ $60{ }^{\circ} \mathrm{C}$ dan temperatur fluida dingin masuk $\left(T_{c, i}\right) 29^{\circ} \mathrm{C}$ pada debit masuk fluida panas $510 \mathrm{l} / \mathrm{jam}$ dan debit masuk fluida dingin $108 l /$ jam sebesar $96.56460 \%$.

2. Sedangkan pada eksperimen didapatkan efektifitas terbesar pada temperatur fluida panas masuk $\left(T_{h, i}\right) 50{ }^{\circ} \mathrm{C}$ dan temperatur fluida dingin masuk $\left(T_{c, i}\right) 29^{\circ} \mathrm{C}$ pada debit masuk fluida panas $510 \mathrm{l} / \mathrm{jam}$ dan debit masuk fluida dingin $180 \mathrm{l} /$ jam yaitu sebesar $35.4040 \%$.

3. Sebagai perbandingan, perhitungan data di lapangan oleh tim riset sebelumnya dengan APK tabung sepusat diperoleh efektifitas APK minimum adalah 4,62875\% pada temperatur fluida panas masuk $\left(T_{h, i}\right) 40{ }^{\circ} \mathrm{C}$ dan temperatur fluida dingin masuk $\left(T_{c, i}\right) 30^{\circ} \mathrm{C}$ pada debit masuk fluida panas $180 \mathrm{l} / \mathrm{jam}$ dan debit masuk fluida dingin $180 \mathrm{l} / \mathrm{jam}$. Sedangkan efektifitas APK maksimum adalah 31,00435\% pada temperatur fluida panas masuk $\left(T_{h, i}\right) 55^{\circ} \mathrm{C}$ dan temperatur fluida dingin masuk $\left(T_{c, i}\right) 32{ }^{\circ} \mathrm{C}$ pada debit masuk fluida panas $180 l / j a m$ dan debit masuk fluida dingin $420 \mathrm{l} / \mathrm{jam}$. Sedangkan perhitungan data pada APK shell \& tube didapatkan nilaiefektifitas APK maksimum yaitu $35.4040 \%$ pada temperatur fluida panas masuk $\left(T_{h, i}\right) 50{ }^{\circ} \mathrm{C}$ dan temperatur fluida dingin masuk $\left(T_{c, i}\right) 32{ }^{\circ} \mathrm{C}$ pada debit masuk fluida panas $510 \mathrm{l} / \mathrm{jam}$ dan debit masuk fluida dingin $180 \mathrm{l} / \mathrm{jam}$. Nilai efektifitas didapatkan mempunyai perbedaan yang cukup signifikan, hal tersebut dikarenakan terdapat perbedaan material dari tabung apk tersebut. Pada tabung dalam APK shell \& tube, material yang digunakan adalah tembaga dengan nilai konduktivitas sebesar $385 \mathrm{~W} / \mathrm{mK}$ sedangkan pada APK tabung sepusat, material yang digunakan adalah aluminium dengan nilai konduktivitas sebesar $205 \mathrm{~W} / \mathrm{mK}$.

4. Temperatur fluida panas dan fluida dingin efektif yang keluar dari alat penukar kalor shell and tube adalah untuk hasil eksperimen diperoleh pada debit aliran fluida dingin $108 \mathrm{l} / \mathrm{j}$ untuk suhu fluida panas $40^{\circ} \mathrm{C}$ didapat sebesar $39.6^{\circ} \mathrm{C}(\mathrm{Th})$ dan 33.7 (Tc) , dan untuk hasil teori diperoleh pada debit aliran fluida dingin $108 \mathrm{l} / \mathrm{j}$ untuk suhu fluida panas $40^{\circ} \mathrm{C}$ didapat sebesar $38.8037 \%$ (Th) dan $29.1963 \%$ (Tc) .

5. Diperloleh hasil keefektifan maksimum dari eksperimen sebesar $45.3965 \%$ pada keadaan kapasitas aliran fluida panas $510 \mathrm{~L} / \mathrm{jam}$ dengan suhu $40^{\circ} \mathrm{C}$ dan aliran fluida dingin $108 \mathrm{~L} / \mathrm{jam}$ dengan suhu $27.8^{\circ} \mathrm{C}$. dan hasil keefektifan alat penukar kalor maksimum dari hasil teori (Metode NTU) sebesar $97.396 \%$ pada keadaan kapasitas aliran fluida panas $510 \mathrm{~L} / \mathrm{jam}$ dengan suhu $40^{\circ} \mathrm{C}$ dan aliran fluida dingin $108 \mathrm{~L} / \mathrm{jam}$ dengan suhu $28^{\circ} \mathrm{C}$.

6. Pada alat penukar kalor shell and tube hasil efektivitas eksperimen maksimum diperoleh sebesar $45.3965 \%$ pada keadaan kapasitas aliran fluida panas $510 \mathrm{~L} / \mathrm{jam}$ dengan suhu $40^{\circ} \mathrm{C}$ dan aliran fluida dingin $108 \mathrm{~L} / \mathrm{jam}$ dengan suhu $28^{\circ} \mathrm{C}$, sedangkan pada alat penukar kalor tabung sepusat diperloleh hasil efektivitas eksperimen maksimum sebesar $21.66956522 \%$ pada keadaan kapasitas aliran fluida panas $300 \mathrm{~L} / \mathrm{jam}$ dengan suhu $55^{\circ} \mathrm{C}$ dan aliran fluida dingin $240 \mathrm{~L} / \mathrm{jam}$ dengan suhu $32^{\circ} \mathrm{C}$. 


\subsection{Ucapan Terima Kasih}

Penulis menyampaikan ucapan terima kasih kepada Direktorat Jenderal Pendidikan Tinggi Kementerian Riset Pendidikan Tinggi dan Lembaga Penelitian Universitas Sumatera Utara yang telah membiayai kegiatan ini melalui penelitian DRPM KEMENRISTEKDIKTI untuk tahun anggaran 2017.

\section{Referensi}

[1] Incropera, Frank P., David P. Dewitt. 1985. Fundamentals of Heat and Mass Transfer, Second Edition. John Wiley \& Sons Inc. : New York

[2] Mullen(2015).Thermo Siphon Re-Boiler .From http://www.slideshare.net/ carawebbumllen/distillation-basic-training.

[3] Tejas M Ghiwala and Dr V k Matawla (2014) Heat exchanger : Triple concentric,Double Pipe, Sizing, Overall Heat Transfer Coefficients. ISSN 2321-9939

[4] Sadik Kakac and Hongtan Liu (March 2002). Heat Exchangers: Selection, Rating and Thermal Design (2nd Edition ed.). CRC Press. ISBN 08493-0902-6

[5] Yunus A. Cengel.2002. HeatTransfer A Practical Approach, Second Edition.Mc Graw-Hill, Book Company, Inc : Singapore

[6] Acusim(2015). Konstruksi alat penukar kalor Sumber :http://.acusim.com-/images/apps/pfhx.jpg

[7] Muchlis (2013).Alat Penukar Kalor. From http://muchlis88.blogspot.com/2011/01/8-alat-penukar-kalor.html, 22 Juli 2015.

[8] Dytrade (2015).Evaporator .From www.dytrade.com

[9] Aolan (2015) . Cooler. From www.Aolan-China.com

[10] John (2015). Heat Exchanger Counter Flow Engineering Excel Spreads Sheets Sumber http://www.engineeringexcelspreadsheets.com/wp content/uploads/2011/08/double-pipe-heat-exchanger_counterflow-w-temps.jpg

[11] Peter (2013). Hairpin Heat Exchanger .From www.lv-soft.com

[12] Cheresources (2010). Shell and Tube Heat Exchanger. From www.cheresources.com

[13] Insiyoer ( 2015 ). Pressure Safety Valve. From www.insiyoer.com

[14] Eryhartoyo(2012).JenisJenisValve.From:https://eryhartoyo.wordpress.com/2012/08/14/jenis-jenis-valve/.

[15] ejournal.unsri.ac.id/index.php/jrm/article/download/76/pdf 